\title{
CONGENITAL HYPERTROPHIC PYLORIC STENOSIS IN TWINS
}

\author{
BY \\ JULIUS D. METRAKOS \\ From the Department of Medical Genetics of The Children's Memorial Hospital and the Department of Genetics, \\ McGill University, Montreal
}

(RECEIVED FOR PUBLICANION JUNE 8, 1953)

\begin{abstract}
Szilagyi and McGraw in 1943 aptly pointed out that

'When a disease has ceased to be a therapeutic problem, scientific interest in it is likely to wane. Not infrequently successful measures of treatment are devised before the fundamental problems of a disease have been solved, and in such instances the consequent lack of interest will be reflected in the neglect of the related, less practical but basically important, questions.'
\end{abstract}

The purpose of this paper is to present briefly the medico-surgical histories of eight new cases of hypertrophic pyloric stenosis occurring in five pairs of twins, and by an analysis of the literature on twins and by the application of the 'twin method' to look into some 'of the related, less practical but basically important' questions pertaining to the relative role of heredity and environment in the aetiology of hypertrophic pyloric stenosis of infancy.

\section{The 'Twin Method'}

The value of the 'twin method' is based on the fact that there are two distinct types of twins. The monozygous or identical twins, because of their development from a single fertilized ovum, have, gene for gene, identical genetic constitutions. The dizygous or fraternal twins, on the other hand, because of their development from two separate fertilized ova, differ in many genes, and are no more alike genetically than siblings who are born separately. If in an unselected series of twins it is found that the condition under investigation occurs far more frequently in both of monozygotic than in both of dizygotic twins, it is justifiable to conclude that the higher degree of concordance among the monozygotic group is indicative of a genetic aetiology. The importance of the environmental influences may be estimated from the amount of discordance found among monozygotic twins. When the degree of concordance among monozygotic twins is no greater than among dizygotic twins, then it is very likely that environment is the primary aetiological factor. The usefulness of the 'twin method' of study is completely lost, however, unless numerous biases that may occur from various sources are avoided or kept at a minimum. The nature of some of these biases is discussed later when the literature is reviewed.

\section{Case Histories}

The summaries of eight case histories of patients who are twins are presented below. Three of the twin pairs are concordant; therefore only five sets, four of like and one of unlike sexes, are involved. The similarities between pairs in physical appearance (hair and eye colour, iris pattern, ear and nose shape, etc.), finger prints, blood groups $\left(O, A_{1}, A_{2}\right.$, B, M, N, C, D, E, c, e) and ability to taste PTC (two of the pairs were too young to be tested for this characteristic) support a diagnosis of monozygosity in all four sets of twins of like sex. The close agreement between co-twins in the above tests makes it highly improbable that any one of the four like-sexed pairs is dizygotic. Three of the twin pairs (Table 1, Nos. 129, 131 and 132) were admitted to the Children's Memorial Hospital and thus came to my attention. The other two pairs (Table 1, Nos. 128 and 130), admitted to the Royal Victoria Hospital, Montreal, by Dr. A. K. Geddes, were referred to me for genetic study.

Cases 1 and 2. Twin pair No. 128 (born October 25, 1947). This pair of monozygous twin girls was first seen by me when almost 4 years old and in good health. Although a complete family history could not be obtained, it is known that the twins were the result of the first pregnancy of a young, unwed, 22-year-old woman. The birth was two weeks premature but uncomplicated.

Twin A (first born, birth weight $4 \mathrm{lb} .12 \mathrm{oz}$.) developed normally until 4 weeks old when she began to vomit. She was admitted to the Royal Victoria Hospital at the age of 6 weeks, at which time the vomiting was projectile. The physical examination revealed a small movable 
tumour about 1.5 in. above and to the right of the umbilicus. Radiological examination following a barium meal confirmed the diagnosis of hypertrophic pyloric stenosis. She was cured by a Fredet-Rammstedt pyloromyotomy.

Twin B (second born, birth weight $5 \mathrm{lb} .4 \mathrm{oz}$.) has a medical history almost identical with that of her twin sister except that her symptoms began about 10 days earlier and were a little more severe. Here, too, the diagnosis was confirmed at operation.

Cases 3 and 4. Twin pair No. 129 (born March 9, 1951) of monozygotic boys was admitted to the Children's Memorial Hospital at the age of 8 weeks. The twins, the product of the fifth pregnancy of a 35-year-old woman, were born two weeks prematurely.

On admission Twin A (birth weight $5 \mathrm{lb} .14 \mathrm{oz}$.) had projectile vomiting, constipation and loss of weight. Peristaltic waves were visible during a feeding and a tumour was palpated in the area of the pylorus. Three days after admission a Fredet-Rammstedt pyloromyotomy was performed and the diagnosis of hypertrophic pyloric stenosis was confirmed.

Twin B (birth weight $6 \mathrm{lb}$. $3 \mathrm{oz}$.) was admitted at the same time and with the same symptoms as his identical twin. The diagnosis was confirmed at operation.

The parents and four older siblings are alive and well. The mother reports that she had influenza during the last trimester of the pregnancy otherwise the prenatal history is not informative. No history of pyloric stenosis could be found in either the paternal or maternal kindreds. There is no parental consanguinity.

Cases 5 and 6. Twin pair No. 130 (born March 8, 1947) of monozygous boys were first seen by me when they were 4 years old and in excellent health. Their birth, which was one month premature, ended the second pregnancy of a 30-year-old woman. Both twins were admitted to the Royal Victoria Hospital at the age of 6 weeks with similar symptoms.

Twin A (birth weight $5 \mathrm{lb}$. $1 \mathrm{oz}$.) had taken his feeds well for a few days after discharge from the maternity hospital, but then began to vomit most of them. The vomiting became projectile and he was admitted to the hospital. The physical examination revealed a small, hard tumour in the right upper quadrant. A diagnosis of hypertrophic pyloric stenosis was confirmed at operation on the following day. He was discharged but had to be readmitted two weeks later because of "pylorospasm". There was gradual improvement and he was discharged cured.

Twin B (birth weight $6 \mathrm{lb}$.) developed similar symptoms at about the same time as his twin brother. The diagnosis of hypertrophic pyloric stenosis was confirmed at operation. He, too, developed 'post-operative pylorospasm' and was readmitted at the same time as his twin. On his second admission he remained in hospital for 10 days during which time he improved markedly and was discharged.

The parents and one older sister of the twins have no pertinent medical history. No history of pyloric stenosis could be found. There is no parental consanguinity.
Case 7. Twin pair No. 131 was born on July 3, 1952. The male of these unlike sexed twins was admitted to the Children's Memorial Hospital when he was about 6 weeks old. The twins, born at term, are the product of the third pregnancy of a 35-year-old woman.

Twin A (birth weight $5 \mathrm{lb}$. $14 \mathrm{oz}$.) was seen at the time her twin brother was admitted to hospital and again when 8 months old. She appeared to be in excellent health, had gained weight constantly and had never had any symptoms comparable to those of her twin.

Twin B (birth weight $7 \mathrm{lb}$. 5 oz.) has a history of projectile vomiting since 3 weeks of age. When admitted to the hospital he appeared well nourished, was in no distress but vomited most of his feeds. The first radiological examination showed a long, extremely thin pyloric canal with small amounts of barium in it. In subsequent films, however, a well formed duodenal cap with barium scattered through the upper small bowel could be seen. Because of projectile vomiting in the absence of radiological evidence of obstruction, a tentative diagnosis of pylorospasm was made and the child was placed on sedation, antispasmodics and thickened feeds. However, the vomiting continued and the child did not improve as rapidly as expected. Five days after admission a barium meal was given and radiographs were repeated. There was a definite obstruction at the pylorus and a diagnosis of hypertrophic pyloric stenosis was made, confirmed the following day by pyloromyotomy.

In this family the father and one older sister are alive and well. The mother had scarlet fever when 9 years old and petit mal attacks ever since. There is no history of pyloric stenosis in either the paternal or maternal kindreds and no parental consanguinity.

Case 8. Twin pair No. 132 was born on December 9, 1952. Twin A of this pair of monozygous twin girls was admitted to the Children's Memorial Hospital when she was about 7 weeks old. The twins were born at term after the third pregnancy of a 27-year-old woman.

Twin A (birth weight $5 \mathrm{lb}$. $5 \mathrm{oz}$ ) had a history of projectile vomiting. There was a small, hard tumour in the right upper quadrant. The diagnosis of hypertrophic pyloric stenosis was confirmed two days later when a pyloromyotomy was performed. Recovery was uneventful and the child was discharged.

Twin B (birth weight $6 \mathrm{lb} .8 \mathrm{oz}$.) was seen at home at the same time that her twin sister was admitted to hospital, and again when 4 months old. She is in excellent health, has gained weight constantly, and has never had any symptoms comparable to those of her sister.

The parents have no pertinent medical history. Two previous pregnancies both terminated as miscarriages. There is no history of pyloric stenosis, and there is no parental consanguinity.

All eight infants had typical signs and symptoms of hypertrophic pyloric stenosis. This diagnosis was confirmed in all eight cases when a FredetRammstedt pyloromyotomy was performed. With the possible exception of Pair No. 130 that developed post-operative pylorospasm, there were no serious 
complications and all eight recovered completely. The antenatal history was not informative for all five pregnancies. The prematurity of two, two and four weeks in the first three pairs is probably related to the multiple birth rather than to any other cause. No history of pyloric stenosis was obtained among the six siblings (three boys and three girls) nor among other near relatives (parents, grandparents, paternal and maternal siblings, and offspring of paternal and maternal siblings). None of the five matings was consanguineous. The similarities in the four like-sexed twins are in favour of uniovular development. There is little doubt therefore that the four like-sexed pairs of twins are monozygous and concordant in three cases, and monozygous and discordant in one case. The one unlike-sexed pair of twins is, of course, dizygotic and at eight months has remained discordant.

\section{Review of the Literature}

In Table 1 are listed in the chronological order of their appearance in the literature 132 pairs of twins where at least one member of each pair was affected with 'hypertrophic pyloric stenosis'. This list is composed of 127 pairs taken from the literature and of the five new pairs reported above. The words 'hypertrophic pyloric stenosis' are purposely placed in quotation marks because a diagnosis of hypertrophic stenosis in a few cases which have appeared in review articles is not supported when the original paper is examined. Indeed, in at least one instance the original report was never intended to be one of hypertrophic pyloric stenosis. The zygosity and concordance or discordance that are given in the table are those reported by the original author. Under 'Remarks' is given the main reason why the case is not included in the final analysis of this review.

TABLE 1

ZYGOSITY AND CONCORDANCE AS INDICATED BY ORIGINAL AUTHOR OF 132 PAIRS OF TWINS WITH HYPERTROPHIC PYLORIC STENOSIS

\begin{tabular}{|c|c|c|c|c|c|c|c|c|c|c|}
\hline & & Type & & & Birth & Order & & & & Remarks \\
\hline Pair & & Pair & $\mathbf{U}$ & 1 & 2 & 3 & 4 & 5 & 6 & \\
\hline $\begin{array}{r}1 \\
2 \\
3 \\
4 \\
5 \\
6 \\
7 \\
8 \\
9 \\
10 \\
11-13 \\
14 \\
15 \\
16 \\
17 \\
18 \\
19 \\
20 \\
21 \\
22 \\
23 \\
24 \\
25 \\
26-27 \\
28-29 \\
30 \\
31 \\
32 \\
33-43 \\
44-53 \\
54 \\
55 \\
56 \\
57-58 \\
59 \\
60 \\
61-64 \\
65 \\
66-68 \\
69 \\
70 \\
71-74 \\
75 \\
76 \\
77 \\
79\end{array}$ & $\begin{array}{l}\text { McKechnie (1913) } \\
\text { Thomson (1921) } \\
\text { Redlin (1923) } \\
\text { Moore (1924) } \\
\text { Sauer (1924) } \\
\text { Davis (1924) } \\
\text { Lasch (1925) } \\
\text { Verschuer (1927) } \\
\text { Bilderback (1928) } \\
\text { Cockayne and Sheldon } \\
\text { (1928) } \\
\text { Monrad (1928) } \\
\text { Glatzel (1931) } \\
\text { Sommer (1931) } \\
\text { Varden (1933) } \\
\text { Lanz (1934)* } \\
\text { Brauns (1934)* } \\
\text { Redgate (1935) } \\
\text { Gelder (1936) } \\
\text { Schippers and Molen (1936) } \\
\text { De Lange (1936) } \\
\text { Halbertsma (1936) } \\
\text { Knauet (1937) } \\
\text { Wallgren (1937) } \\
\text { Wallgren (1937) } \\
\text { Wallgren (1937) } \\
\text { Schmid (1938) } \\
\text { Sheldon (1938) } \\
\text { Sheldon (1938) } \\
\text { Sheldon (1938) } \\
\text { Sbeldon (1938) } \\
\text { Pouyanne (1938) } \\
\text { Card (1939) } \\
\text { Runström (1939) } \\
\text { Rinvik (1940) } \\
\text { Robertson (1940) } \\
\text { Robertson (1940) } \\
\text { Robertson (1940) } \\
\text { Robertson (1940) } \\
\text { Robertson (1940) } \\
\text { Robertson (1940) } \\
\text { Robertson (1940) } \\
\text { Levi (1941) } \\
\text { O'Donnell and Klein (1941) } \\
\text { Cockayne and } \\
\text { (1943) } \\
\text { Cockayne and Penrose } \\
\text { (1943) }\end{array}$ & $\begin{array}{l}\mathbf{D Z} \\
\mathbf{N S} \\
\mathbf{N S} \\
\mathbf{N S} \\
\mathbf{N S} \\
\mathbf{M Z} \\
\mathbf{M Z} \\
\mathbf{N S} \\
\mathbf{M Z} \\
\mathbf{N S} \\
\mathbf{N S} \\
\mathbf{M Z} \\
\mathbf{M Z} \\
\mathbf{M Z} \\
\mathbf{D Z} \\
\mathbf{M Z} \\
\mathbf{M Z} \\
\mathbf{M Z} \\
\mathbf{M Z} \\
\mathbf{D Z} \\
\mathbf{N S} \\
\mathbf{D Z} \\
\mathbf{N S} \\
\mathbf{N S} \\
\mathbf{M Z} \\
\mathbf{M Z} \\
\mathbf{D Z} \\
\mathbf{D Z} \\
\mathbf{N S} \\
\mathbf{M Z} \\
\mathbf{M Z} \\
\mathbf{N S} \\
\mathbf{N S} \\
\mathbf{M Z} \\
\mathbf{M Z} \\
\mathbf{D Z} \\
\mathbf{D Z} \\
\mathbf{D Z} \\
\mathbf{D Z} \\
\mathbf{M Z} \\
\mathbf{N S} \\
\mathbf{D Z} \\
\mathbf{D Z} \\
\mathbf{N S}\end{array}$ & 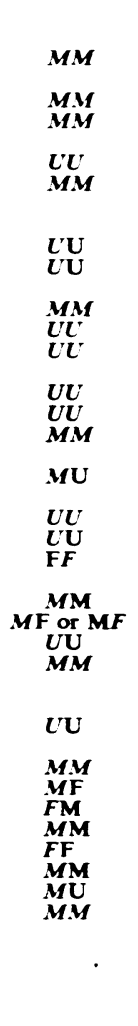 & $\begin{array}{l}\text { MF } \\
M U \\
M M\end{array}$ & $\begin{array}{l}\text { FU } \\
M M\end{array}$ & $\begin{array}{r}\mathbf{M} \\
\mathbf{M F}\end{array}$ & $\mathbf{M}$ & $\mathbf{M F}$ & $\mathbf{M}$ & $\begin{array}{l}\text { Adequately reported } \\
\text { Zygosity } \\
\text { Zygosity } \\
\text { Zygosity } \\
\text { Zygosity } \\
\text { Zygosity } \\
\text { Diagnosis } \\
\text { Diagnosis and zygosity } \\
\text { Zygosity } \\
\text { Adequately reported } \\
\text { Zygosity (3 pairs) } \\
\text { Zygosity } \\
\text { Zygosity } \\
\text { Adequately reported } \\
\text { (Zygosity) } \\
\text { (Zygosity) } \\
\text { Adequately reported } \\
\text { (Zygosity)* } \\
\text { (Zygosity)* } \\
\text { Adequately reported } \\
\text { Adequately reported } \\
\text { Zygosity. } \\
\text { Diagnosis of co-twin } \\
\text { Zygosity (2 pairs) } \\
\text { Zygosity (2 pairs) } \\
\text { Diagnosis } \\
\text { Adequately reported } \\
\text { Adequately reported } \\
\text { Adequately reported (11 pairs) } \\
\text { Zygosity (10 pairs) } \\
\text { Zygosity } \\
\text { Adequately reported } \\
\text { Zygosity } \\
\text { Zygosity (2 pairs) } \\
\text { Adequately reported } \\
\text { Adequately reported } \\
\text { Adequately reported (4 pairs) } \\
\text { Adequately reported } \\
\text { Adequately reported (3 pairs) } \\
\text { Adequately reported } \\
\text { Zygosity } \\
\text { Zygosity (4 pairs) } \\
\text { Zygosity } \\
\text { Adequately reported } \\
\text { Zygosity }\end{array}$ \\
\hline
\end{tabular}


TABLE 1-continued.

\begin{tabular}{|c|c|c|c|c|c|c|c|c|c|c|}
\hline \multirow{2}{*}{$\begin{array}{l}\text { Twin } \\
\text { Pair }\end{array}$} & \multirow{2}{*}{ Author and Year } & \multirow{2}{*}{$\begin{array}{l}\text { Type } \\
\text { of } \\
\text { Pair }\end{array}$} & \multicolumn{7}{|c|}{ Birth Order } & \multirow[t]{2}{*}{ Remarks } \\
\hline & & & $\mathbf{U}$ & 1 & 2 & 3 & 4 & 5 & 6 & \\
\hline $\begin{array}{r}78 \\
79 \\
80 \\
81 \\
82 \\
83 \\
84 \\
85 \\
86 \\
87 \\
88 \\
89 \\
90-91 \\
92-96 \\
97 \\
98 \\
99 \\
100 \\
101-102 \\
103-104 \\
105 \\
106 \\
107 \\
108 \\
109 \\
110 \\
111 \\
112 \\
113 \\
114 \\
115 \\
116 \\
117 \\
118 \\
119 \\
120 \\
121 \\
122 \\
123 \\
124 \\
125 \\
126 \\
127 \\
128 \\
129 \\
130 \\
131 \\
132\end{array}$ & $\begin{array}{l}\text { Cockayne and Penrose } \\
\text { (1943) } \\
\text { Cockayne and Penrose } \\
\text { (1943) } \\
\text { Cockayne and Penrose } \\
\text { (1943) } \\
\text { Cockayne and Penrose } \\
\text { (1943) } \\
\text { Cathala and Cler (1944) } \\
\text { Lewis (1944) } \\
\text { Donovan (1946) } \\
\text { Donovan (1946) } \\
\text { Ladd et a. (1946) } \\
\text { Nafe (1947) } \\
\text { Laubscher and Smith (1947) } \\
\text { Murphy (1947) } \\
\text { Schaefer and Erbes (1948) } \\
\text { Schaefer and Erbes (1948) } \\
\text { Lamy et al. (1949) } \\
\text { Hughes et al. (1949) } \\
\text { Garrison (1949) } \\
\text { Schaper (1950) } \\
\text { Ward-McQuaid and Porritt } \\
\text { (1950) } \\
\text { Grimes et al. (1950) } \\
\text { Grimes et al. (1950) } \\
\text { Wagner and Baratz (1951) } \\
\text { Powell and Carter (1951) } \\
\text { Powell and Carter (1951) } \\
\text { Powell and Carter (1951) } \\
\text { Powell and Carter (1951) } \\
\text { McKeown et al. (1951) } \\
\text { McKeown et al. (1951) } \\
\text { McKeown et al. (1951) } \\
\text { McKeown et al. (1951) } \\
\text { McKeown et al. (1951) } \\
\text { McKeown et al. (1951) } \\
\text { McKeown et al. (1951) } \\
\text { McKeown et al. (1951) } \\
\text { McKeown et al. (1951) } \\
\text { McKeown et al. (1951) } \\
\text { McKeown et al. (1951) } \\
\text { Welsh (1951) } \\
\text { Baker and Sager (1951) } \\
\text { Baker and Sager (1951) } \\
\text { Baker and Sager (1951) } \\
\text { Cunningham and Kelly } \\
\text { (1952) } \\
\text { Sale (1953) } \\
\text { Metrakos (1953) } \\
\text { Metrakos (1953) } \\
\text { Metrakos (1953) } \\
\text { Metrakos (1953) } \\
\text { Metrakos (1953) } \\
\text { Maks }\end{array}$ & $\begin{array}{l}\text { NS } \\
\text { NS } \\
\text { NS } \\
\text { MZ } \\
\text { DZ } \\
\mathbf{M Z} \\
\mathbf{M Z} \\
\mathbf{D Z} \\
\mathbf{D Z} \\
\mathbf{N S} \\
\mathbf{N S} \\
\mathbf{N S} \\
\mathbf{M Z} \\
\mathbf{D Z} \\
\mathbf{M Z} \\
\mathbf{M Z} \\
\mathbf{D Z} \\
\mathbf{D Z} \\
\mathbf{M Z} \\
\mathbf{M Z} \\
\mathbf{M Z} \\
\mathbf{M Z} \\
\mathbf{D Z} \\
\mathbf{M Z} \\
\mathbf{N S} \\
\mathbf{N S} \\
\mathbf{N S} \\
\mathbf{N S} \\
\mathbf{N S} \\
\mathbf{N S} \\
\mathbf{N S} \\
\mathbf{N S} \\
\mathbf{N S} \\
\mathbf{D Z} \\
\mathbf{N S} \\
\mathbf{M Z} \\
\mathbf{N S} \\
\mathbf{N S} \\
\mathbf{N S} \\
\mathbf{M Z} \\
\mathbf{M Z} \\
\mathbf{M Z} \\
\mathbf{M Z} \\
\mathbf{M Z} \\
\mathbf{D Z} \\
\mathbf{M Z}\end{array}$ & 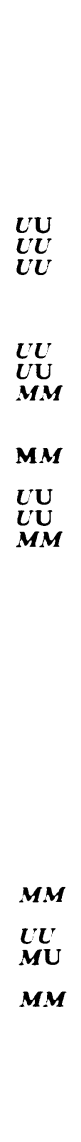 & $\begin{array}{c}\mathbf{M M} \\
\mathbf{S} \\
\mathbf{M} \\
\mathbf{M} \\
\mathbf{F} \\
\mathbf{F} \\
\mathbf{M} \mathbf{M} \\
\boldsymbol{F} \mathbf{F} \\
\mathbf{M} \\
\mathbf{M} \\
\mathbf{M} \\
\mathbf{F} \\
\mathbf{M} \\
\boldsymbol{F} \mathbf{F} \\
\mathbf{M F} \\
\mathbf{M} \mathbf{M} \\
\mathbf{M}\end{array}$ & $\begin{array}{c}\mathbf{M} \mathbf{M} \\
\mathbf{F} \\
\mathbf{F} \\
\mathbf{S} \\
\mathbf{M} \\
\\
\mathbf{M} \\
\mathbf{F} \\
\mathbf{F} \\
\mathbf{M} \\
\mathbf{M} \\
\mathbf{M} \\
\mathbf{M}) \\
\boldsymbol{U} \boldsymbol{U}\end{array}$ & 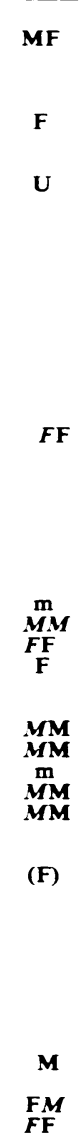 & $\begin{array}{l}M M \\
\text { (M) } \\
\text { (F) }\end{array}$ & MM & & $\begin{array}{l}\text { Adequately reported } \\
\text { Adequately reported } \\
\text { Zygosity } \\
\text { Zygosity } \\
\text { Zygosity } \\
\text { Diagnosis of co-twin } \\
\text { Not original case } \\
\text { Not original case } \\
\text { Zygosity } \\
\text { Zygosity } \\
\text { Zygosity } \\
\text { Zygosity } \\
\text { Zygosity and diagnosis (2 pairs) } \\
\text { Zygosity (5 pairs) } \\
\text { Adequately reported } \\
\text { Adequately reported } \\
\text { Adequately reported } \\
\text { Diagnosis } \\
\text { Zygosity (2 pairs) } \\
\text { Zygosity (2 pairs) } \\
\text { Zygosity } \\
\text { Zygosity } \\
\text { Adequately reported } \\
\text { Adequately reported } \\
\text { Diagnosis of co-twin } \\
\text { Adequately reported } \\
\text { Zygosity } \\
\text { Zygosity } \\
\text { Zygosity } \\
\text { Zygosity } \\
\text { Zygosity } \\
\text { Zygosity } \\
\text { Zygosity } \\
\text { Zygosity } \\
\text { Zygosity } \\
\text { Adequately reported } \\
\text { Zygosity } \\
\text { Zygosity } \\
\text { Zygosity } \\
\text { Zygosity } \\
\text { Zygosity }\end{array}$ \\
\hline & $\begin{array}{l}\text { Dizygous } \\
\text { Not stated }\end{array}$ & $\begin{array}{l}\text { laffecter } \\
\text { known }\end{array}$ & & not & & & & & & \\
\hline
\end{tabular}

Whenever the 'twin method' is employed in order to evaluate the relative roles of heredity and environment as aetiological factors in the production of a specific characteristic, four conditions must be rigidly met before an analysis is undertaken. The validity of conclusions derived by the twin method of investigation is directly proportional to the care exercised in observing these conditions.

First, the diagnostic criteria which will constitute a 'case' must be well defined and no individual must be included in the analysis who does not satisfy these criteria. The signs and symptoms of hypertrophic pyloric stenosis are clear cut and the diagnosis as a rule is made readily; however, because of the occasional difficulty that is encountered in differentiating between pylorospasm and hypertrophic pyloric stenosis (as evidenced by the seventh case history given above), and because sufficient diagnostic evidence is not always given, it has been decided to accept for final analysis only those cases that had a hypertrophic pylorus positively identified either at operation or at necropsy. It is admitted that this procedure will eliminate many reports which are indeed of pyloric stenosis, but it was felt that it was better to exclude some true cases than to include some false ones.

Secondly, the concordance or discordance of the twins must be accurately established. This is of 
particular importance in discordant pairs for the well twin must be seen and examined before being pronounced unaffected.

Thirdly, there must be ample evidence that the zygosity of the twins is as stated. Monozygosity must not be based only on apparent similarities of general features but must also be supported by either $(a)$ the identification of a single chorion, or (b) a battery of tests including, whenever possible, blood groups and finger-prints. The assumption that the presence of one placenta is indicative of monozygotic twinning and that two placentae indicate dizygotic twinning was proven erroneous by Steiner in 1935 , yet many continue to use the condition of the placenta as a criterion of zygosity.

Finally, there must be no bias in the selection of twins, that is, monozygosity or dizygosity and concordance or discordance must not influence whether the twin pair is reported or not. A good criterion of an unselected twin series is that the monozygosity to dizygosity ratio is not significantly different from 1 to 2, i.e. approximately the ratio that the two groups are found in the population from which the twins are drawn. Depending on how rigidly these conditions are observed, the following three analyses may be undertaken:

Analysis I. If all the 132 twin pairs with hypertrophic pyloric stenosis' are included, there are 35 monozygous, 40 dizygous, and 57 with zygosity not stated. The concordance in the three groups is $71 \cdot 4^{\circ}, 17 \cdot 5^{\circ}$ o and $29 \cdot 8^{\circ}$ o respectively (Table 2 ). On the expectation of one monozygotic to two dizygotic twin pairs it seems that there has been a tendency to report monozygous twin pairs far more often than dizygous ones for they constitute $46 \cdot 7^{\circ}$, of the total instead of the expected $33^{\circ}$. This bias becomes of paramount importance if a further selection for monozygous concordant pairs has occurred, for this places undue emphasis on the role of heredity while minimizing that of environment. Unfortunately, in reviews of the literature such as this, this type of bias is usually present, and it is impossible to assess its extent properly.

Analysis II. If cases with a stated zygosity which was not confirmed at operation or necropsy are now excluded from the analysis, then pairs Nos. 7 , $8,25,30,83,100$ and 109 must be omitted.

In addition to the above seven pairs there are also nine other pairs (Nos. 3, 24, 56, 71-74 and 90-91) all belonging to the group where zygosity is not stated, which must be excluded because they do not fulfil the requirements regarding the diagnosis of 'affected' and 'not affected'. Since the zygosity of these nine pairs of twins is not stated, further elaboration on the reasons for their omission is not necessary.

When all the incompletely or inaccurately diagnosed cases are omitted, and also the twin pairs whose zygosity is not known, there are 30 monozygous and 38 dizygous twin pairs remaining. The concordance is $76 \cdot 7^{\circ}$ ond $13 \cdot 2^{\circ}$ o for the monozygotic and dizygotic groups (Table 2). It is pointed out that the monozygous group constitutes $44 \cdot 1^{\circ}$ o of all twins with a stated zygosity. This figure approximates the expected $33^{\circ}{ }_{0}$ a little more closely than the figure $\left(46 \cdot 7^{\circ}\right.$ ) obtained in Analysis $I$.

Analysis III. If, from the twin pairs remaining after Analysis II, the pairs whose zygosity is determined on inaccurate or insufficient grounds are excluded, then pairs Nos. 15, 17-18, 20-21, 54, 70, $75,84,88,101-106,122$ and 128 must be omitted.

When the twin pairs with insufficient reported evidence for their zygosity are omitted from the analysis, 18 monozygous and 29 dizygous twins remain. The concordance of the two groups is $66.7^{\circ}$ o and $3 \cdot 4^{\circ}$ o respectively. Furthermore, the monozygotics constitute $38 \cdot 3^{\circ}$ of the total indicating that this third list of pairs is less biased than either the first or second (Table 2). The 47 pairs of twins that remain for Analysis III are either of unlike sex or ample proof is presented to support the zygosity stated. Furthermore, the diagnosis of the affected individuals has been established either at operation or at necropsy. There is, too, sufficient reason for believing that the unaffected individuals are indeed free of hypertrophic pyloric stenosis.

\section{Discussion}

Aetiology. Flanagan (1951) in his review of the main theories of hypertrophic pyloric stenosis,

TABLE 2

THREE 'PROGRESSIVE' ANALYSES BY THE TWIN METHOD OF 132 PAIRS OF TWINS

\begin{tabular}{|c|c|c|c|c|c|c|c|}
\hline \multirow{2}{*}{$\begin{array}{c}\text { No. of } \\
\text { Pairs }\end{array}$} & \multicolumn{2}{|c|}{ Monozygous } & \multicolumn{2}{|c|}{ Dizygous } & \multicolumn{2}{|c|}{ Not Stated } & \multirow{2}{*}{$\frac{M Z X 100^{\circ}}{M Z-D Z}$} \\
\hline & Concordant & Discordant & Concordant & Discordant & Concordant & Discordant & \\
\hline $\begin{array}{rr}\text { (I) } & 132 \\
\text { (II) } & 68 \\
\text { (III) } & 47\end{array}$ & $\begin{array}{l}71 \cdot 4^{\circ} \circ(25) \\
76 \cdot 7^{\circ}(23) \\
66 \cdot 70^{\circ}(12)\end{array}$ & $\begin{array}{l}28 \cdot 6^{\circ}(10) \\
23 \cdot 3^{\circ} \circ(7) \\
33 \cdot 3^{\circ} \%(6)\end{array}$ & $\begin{array}{r}17 \cdot 5^{\circ} \text { (7) } \\
13 \cdot 2^{\circ} \text { (5) } \\
3 \cdot 4^{\circ} \circ(1)\end{array}$ & $\begin{array}{l}82 \cdot 5 \%(33) \\
86.8 \% \%(33) \\
96 \cdot 6 \%(28)\end{array}$ & $\begin{array}{c}29 \cdot 8^{\circ} \circ(17) \\
-\end{array}$ & $\overline{1}^{70 \cdot 2^{\circ}(40)}$ & $\begin{array}{l}46 \cdot 7 \% \\
44 \cdot 10^{\circ} \\
38 \cdot 3 \%\end{array}$ \\
\hline
\end{tabular}


remarked that 'many theories as to the cause of this condition are advanced but no one has found a single theory that is acceptable: Some of the manifold theories that have been put forward are differential tonicity between the musculature of the pyloric sphincter and the rest of the pyloric canal (Lehmann, 1931); mechanical irritation by the milk curds (Ladd and Gross, 1941): hormonal influence (Stolte, 1929; Malmberg, 1949); hereditary malformations (Torgersen, 1949); atopical embryonic tissue rests (Torkel, 1905); developmental anomaly (Farkas, 1950); seasonal variation (Rinvik, 1940); hyperacidity (McKechnie, 1913); inherited neuropathic taint' (Pitfield, 1925); prenatal swallowing of liquor amnii (MacHaffie, 1927); injury to central nervous system refuted by Lanman (Lanman and Mahoney, 1933); developmental hyperplasia (Donovan, 1937); hypertrophy preceding spasm (Donovan, 1938): Pirie's hypersecretion of epinephrin theory (see MacHaffie, 1927); parallelism between pyloric stenosis in infants and peptic ulcer in adults (Spock, 1944); 'humoral transmission of some product of maternal tension to the foetus' (Spock, 1944); racial disposition refuted by Ladd (Ladd, Ware and Pickett, 1946); genetic (Cockayne and Penrose, 1943; Lamy, Pognan, Marillier, Jammet and Cordier, 1949); and a host of others.

Since none of the proposed theories explains adequately the development of the hypertrophy of the pylorus it will serve no useful purpose to present these in any detail. It may be noted, however, that most of these theoretical considerations rely upon some intra-uterine influence (maternal hormone, etc.) for their explanation. Typical of these is Stolte's theory (1929) which postulated that the maternal hormones responsible for the hypertrophy of the uterus may be transmitted via the placenta to the embryo. Such hormones, Stolte adds, will cause a hypertrophy of the musculature of the uterus in the case of female infants, but a hypertrophy of the pylorus in the case of male infants. Laubscher and Smith (1947) and many others consider this theory untenable: apart from its hypothetical nature, it is difficult to understand why in some cases (16 out of 45 ) only one of male twins is affected, and also why in the majority of instances (23 out of 24), when one of opposite sexed twins is affected the other is normal. The same argument may be applied to other similar theories, and again the evidence obtained from twins speaks against them.

Incidence of the Condition in Twins. In 1938 Sheldon analysed 1,000 cases of pyloric stenosis and found 23 sets of twins among them. From this he correctly calculated that in approximately one case out of $\mathbf{4 0}$ the patient was a twin (Table 3 ). However, he went on to conclude incorrectly that on the basis of one twin birth per 80 , pyloric stenosis was twice as frequent in twins as in single births. Szilagyi and McGraw (1943) and many others accepted Sheldon's conclusion, and some even began to seek explanations for this apparent higher incidence among twins. Indeed in 1941 when Ford, Brown and McCreary found 12 pairs of twins in a series of 436 affected infants (Table 3 ) they concluded that it would seem, therefore, that the environmental handicap imposed before birth on members of multiple sets is one factor inducing the condition of pyloric stenosis'. Spock (1944) too, accepting that the frequency among twins 'is twice as great as in single births', enters into a rather lengthy discussion in an attempt to explain the phenomenon.

It was not until 1947 that Laubscher and Smith (1947) clearly indicated that on the basis of one twin birth in 80 to 90 confinements, one would expect one case of pyloric stenosis to occur in twins for every $40-45$ cases, for in the population as a whole one person in 40-45 will answer in the affirmative to the question, "Are you a twin?", and showed by a table that in three reports with a large number of cases, the overall frequency of twins affected is approximately as expected, namely, 1:39.6.

The three twin pairs (Nos. 129, 131 and 132) which came to my attention through the Children's Memorial Hospital are included in a series of 249 cases which were operated upon for hypertrophic pyloric stenosis. Among these 249 cases there are two additional cases which were one of twins. Both of these twin pairs were like sexed-one two boys, the other two girls - but unfortunately one twin in each case died soon after birth of causes other than pyloric stenosis, and therefore nothing can be said about their zygosity or about their concordance since they died before the average age of onset for hypertrophic pyloric stenosis. Such twin pairs, as has been mentioned earlier, give no information.

In the 249 cases operated on for hypertrophic pyloric stenosis, therefore, there were six individuals representing five pairs of twins who were described by their parents as twins. The ratio of twin to singletons in this series, therefore, is $1: 41 \cdot 5$ (Table 3 ). This ratio is not significantly different from that found in other series and from the twin ratio in the population as a whole.

Concordance in Dizygotic Twins. Five out of 38 pairs of dizygous twins in Analysis II, and one pair out of 29 in Analysis III (Table 2) were concordant for hypertrophic pyloric stenosis. The explanation of concordance in dizygous twins is an easy one, 
TABLE 3

RATIO OF TWIN CASES TO TOTAL NUMBER OF HYPERTROPHIC PYLORIC STENOSIS

\begin{tabular}{|c|c|c|c|c|c|}
\hline \multicolumn{2}{|l|}{ Author } & $\begin{array}{l}\text { Total } \\
\text { Tum- } \\
\text { ber }\end{array}$ & $\begin{array}{c}\text { Sets } \\
\text { of } \\
\text { Twins }\end{array}$ & $\begin{array}{c}\text { Cases } \\
\text { among } \\
\text { Twins }\end{array}$ & Ratio \\
\hline $\begin{array}{l}\text { Monrad (1927) } \\
\text { Sheldon (1938) } \\
\text { Rinvik (1940) } \\
\text { Ford et al. (1941) } \\
\text { Cockayne and Penro } \\
\text { McKeown et al. (19) } \\
\text { Present study }\end{array}$ & $\begin{array}{ll}\ldots & \ldots \\
\ldots & \ldots \\
\ldots & \ldots \\
\ldots & (1943) \\
951) & \ldots \\
\ldots & \ldots\end{array}$ & $\begin{array}{r}288 \\
1,000 \\
137 \\
436 \\
449 \\
489 \\
249\end{array}$ & $\begin{array}{r}3 \\
23 \\
2 \\
12 \\
11 \\
11 \\
5\end{array}$ & $\begin{array}{r}3 \\
24 \\
2 \\
14 \\
13 \\
12 \\
6\end{array}$ & $\begin{array}{l}1: 75 \cdot 0 \\
1: 40 \cdot 7 \\
1: 68 \cdot 5 \\
1: 30 \cdot 1 \\
1: 34 \cdot 5 \\
1: 39 \cdot 8 \\
1: 41 \cdot 5\end{array}$ \\
\hline Total & $\ldots$ & 3,048 & 67 & 74 & $1: 40 \cdot 4$ \\
\hline
\end{tabular}

for whenever a hereditary factor is involved one anticipates that the condition will affect more than one sibling in some families. Cockayne and Penrose (1943) and more recently McKeown, MacMahon and Record (1951) have shown that the incidence of pyloric stenosis among the siblings of affected individuals is about 1 in 20 , i.e. about 20 times more frequent than in the population as a whole. Since genetically, dizygous twins are siblings born together, it should be expected that in about one pair out of 20 dizygous pairs when one is affected the twin will also be affected. The figures $13 \cdot 2^{\circ}$ o (Analysis II) and $3 \cdot 4^{\circ}{ }_{0}$ (Analysis III) are not too far removed from the expected $5^{\circ}{ }_{0}$ concordance.

Discordance in Monozygotic Twins. Although it is comparatively easy to explain concordance among dizygotic twins it is far more difficult to explain adequately why one of monozygous twins may be affected while the genetically identical twin with presumably the same antenatal history is unaffected. According to one of the two "rules" postulated by Sheldon (1938) when pyloric stenosis affects uniovular twins, both infants show the condition;, yet in Analysis III only 12 of the 18 monozygotic twins are concordant. Furthermore the six discordant pairs (Nos. 31, 99, 107, 108, 110 and 132) seem to fulfil the rigid conditions laid down, and therefore it cannot be said that perhaps they are not monozygotic or that the "unaffected" twin is an asymptomatic case.

The two discordant monozygotic pairs (Nos. 31 and 99) of Sheldon (1938) and Garrison (1949) were reported as being monochorionic and, if one accepts the monochorionic report, then this is conclusive evidence for monozygosity. Furthermore in both of these sets of twins there was additional supporting evidence for monozygosity. In Powell and Carter's (1951) three twin pairs (Nos. 107, 108 and 110 ), and in my own case (No. 132) zygosity has been based on many tests, including finger-prints and blood groups, making it highly unlikely that any of these four pairs are dizygotic.
There still remains the argument that the healthy twin may indeed be affected but asymptomatic. This possibility has been ruled out particularly well in the three twin pairs reported by Powell and Carter (1951), for the healthy twin in each case was examined with considerable care including close observation for peristalsis during a feed. In two of the pairs, the normal twin was also examined radiologically, but no obstruction was noted and there was no delay in eliminating the barium. Furthermore, the healthy twin in each of the three cases has remained well.

\section{Summary and Conclusions}

Four monozygotic pairs of twins, three concordant and one discordant for hypertrophic pyloric stenosis, and one dizygotic discordant pair are presented. The five new pairs are combined with 127 pairs reported in the literature and an analysis is made employing the 'twin method'. For the final analysis only those cases were accepted where the hypertrophic pylorus was identified unequivocally at operation or at necropsy, and where there was ample evidence for the reported zygosity. Of the 132 twin pairs only 47 satisfied these conditions. Of these 18 were monozygotic and 29 dizygotic. Twelve $\left(66 \cdot 7^{\circ}{ }_{0}\right)$ of the monozygotic twins were concordant for the condition whereas only one $\left(3 \cdot 49^{\circ}{ }_{0}\right)$ of the 29 dizygotic twins was concordant. From a study of twin cases, therefore, there seems to be little doubt that there is a hereditary factor involved in the aetiology of hypertrophic pyloric stenosis. It also appears evident that some pre- or post-natal factor may be necessary for the development of the hypertrophy, and that such an environmental factor may be effective in one of a twin pair even when the twins are genetically alike.

I would like to express my sincere thanks to Dr. A. K. Geddes of The Children's Memorial Hospital for referring two pairs of twins with hypertrophic pyloric stenosis: to Dr. F. C. Fraser, of the Department of Medical Genetics, The Children's Memorial Hospital and of the Department of Genetics, McGill University, for his most valuable suggestions: and to the FederalProvincial Public Health Fund and the Banting Research Foundation for financial support.

\section{REFERENCES} Baker, R. P. and Sager, W. W. (1951). Clin. Proc. Child. Hosp.,

Bilderback, J. B. (1928). Northw. med., Seattle, 27, 182

Brauns, L. (1934). Z. Kinderforsch. 43, 86. Cited by Gedda (1951). Card, T. A. (1939). J. Pediat., 14. 658.

Cathala, J. and Cler, R. (1944). Arch. franc. Pediat., 2. 66

Cockayne, E. A. and Penrose, L. S. (1943). Ohio J. Sci., 43. 1. Soc. Med., 21, 1260 .

Cunningham, G. C. and Kelty, J. J. (1952). Sth. med. J., Bgham, Ala., 45. 75 .

Davis, H. H. (1924). J. Amer. med. Ass., 83. 686

De Lange, C. (1936). Archives of Disease in Childhood, 11. 39

Donovan, E. J. (1937). J. Amer. med. Ass., 109, 558.

(1938). Amer. J. Surg., 39, 377. 
Donovan, E. J. (1946). Ann. Surg., 124, 708.

Farkas, E. (1950). Ann. paediat., Baset, 174. 385.

Flanagan, H. F. (1951). Minn. Med., 34, 957.

Ford, N. Brown, A. and McCreary, J. F. (1941). .4mer. J. Dis. Child., 61, 41.

Garrison, R. F. (1949). J. Pediat., 35, 207.

Gelder, F. van (1936). Cited by Szilagyi (1943).

Glatzel, H. (1931). Z. klin. Med., 116, 632

Grimes, O. F., Bell, H. G. and Olney, M. B. (1950). J. Pediat., 37, 522.

Halbertsma, T. (1936). Acta paediat., Uppsala, 18, 463.

Hughes, E. S. R., Small, H. A. D. and Macky, J. W. F. (1949). Brit. med.J., $2,741$.

Knaver, H. (1937). Arch. Kinderheilk., 111, 78.

Ladd, W. E. and Gross, R. E. (1941). Abdominai Surgery of Infancy and Childhood. Philadelphia.

-, Ware, P. F. and Picketh, L. K. (1946). J. Amer. med. Ass., 131,647

Lamy, M., Pognan, C., Marillier, J., Jammet, J. and Cordier, P. A. (1949). Sem. Hôp. Paris, 25, 2348.

Lanman, T. H. and Mahoney, P. J. (1933). Surg. Gynec. Obstet., 56. 205 .

Lanz, O. (1934). Ned. T. Geneesk., 78. 355. Cited by Schmid (1938). Lasch, W. (1925). Münch. med. W' schr., 72 . 1155.

Laubscher, J. H. and Smith, A. M. (1947). Amer. J. Dis. Child., 73, 334.

Lehmann W. (1931). Beitr. klin. Chir., 151, 395.

Levi, D. (1941). Brit. med. J., 1, 963.

Lewis, F. L. K. (1944). Ibid., 1, 221.

MacHaffie, L. P. (1927). Canad. med. Ass. J., 17, 946.

Malmbers N. (1949). Acta paediat. Uppsala, 38, 472

McKechnie, R. E. (1913). Canad. med. Ass. J., 3, 566.

McKeown, T., MacMahon, B. and Record, R. G. (1951). Ann. Eugen., Camb., 16, 260.

Monrad, S. (1928). Acta paediat., Uppsala, 7 (suppl. 2), 16.

Moore, H. L. (1924). Sth. med. J., Bgham, Ala., 17, 187.
Murphy, D. P. (1947). Congenital Malformations, 2nd ed. Philadelphia.

Nafe, C. A. (1947). Arch. Surg., Chicago, 54, 555.

O'Donnell F. T. and Klein, J. M. (1941). Amer. J. Dis. Child., 62. 1025 .

Pitfield, R. L. (1925). Med. J. Rec., 122, 148.

Powell, B. W. and Carter, C. O. (1951). Archives of Disease in Childhood, 26, 45.

Pouyanne, L. (1938). Presse med., 46. 774.

Redgate, J. W. (1935). Brit. med. J., 2 725, 875 and 973.

Redlin, G. (1923). Dtsch. med. Wschr., 49, 415.

Rinvik, R (1940). Acta paediat. Uppsala 27, 296

Robertson, D. E. (1940). Ann. Surg., 112, 687

Runström, G. (1939). Acta paediat., Uppsala, 26, 383.

Sale, T. A. (1953). Brit. med. J., 1, 920.

Saver, L. W. (1924). Arch. Pediat. 41, 145.

Schaefer, A. A. and Erbes, J. (1948). Surg. Gynec. Obstet., 86, 45.

Schaper, G. (1950). Kinderärzal. Prax., 18. 244.

Schippers, J. C. and Molen, H. J. van der (1936). Maandschr. Kindergeneesk., 6,83 .

Schmid, W. (1938). Beitr. klin. Chir., 168, 483.

Sheldon, W. (1938). Lancet, 1, 1048.

Sommer, R. (1931). Disch. Z. Chir., 232, 398.

Spock, B. (1944). Psychosom. Med., 6, 162.

Steiner, F. (1935). Arch. Gynäk. 159, 509.

Stolte, K. (1929). Dtsch. med. Wschr., 55, 2007.

Szilagyi, D. E. and McGraw, A. B. (1943). Surgery, 13. 764.

Thomson, J. (1921). Edinburgh med. J., 26, 1.

Torgersen, J. (1949). Acta radiol., Stockh., 32, 435.

Torkel, W. (1905). Virchows Arch. parh. Anat., 180, 316.

Varden, A. E. (1933). J. Pediat., 3, 493.

Verschuer, O. Von (1927). Ergebn. inn. Med. Kinderheilk., 31, 35.

Waner, D. H. and Baratz, J. (1951). Amer. J. Dis. Child., 81, 253.

Wallgren, A. (1937). Mschr. Kinderheilk., 68, 290.

Ward-McQuaid, J. N. and Porritt, B. E. (1950). Lancet, 1, 201.

Weks, J. B. (1951). J. Indiana med. Ass., 44, 762. 